\title{
Peningkatan Kompensasi Terhadap Kinerja Pegawai pada Dinas Perhubungan Kota Jambi
}

\author{
Reni Devita \\ Fakultas Ekonomi Universitas Batanghari \\ Correspondence email: renidevitagafar@yahoo.co.id
}

\begin{abstract}
The research method used in this research is descriptive and quantitative methods. The quantitative descriptive method aims to describe the nature of something that is ongoing at the time the research is conducted and examines the causes of a particular phenomenon. The data that will be collected will be analyzed, including secondary data analyzed descriptively, while primary data will be analyzed using analytical tools using SPSS program tools. Before the data is used in the SPSS program, the ordinal data is first used as an interval using the method of success interval (MSI) program. From the total population of 124 people studied, the sample became 55 Employees At The Transportation Office Jambi City The results of the study are as follows Compensation with an average score of 268.2 when viewed on the scale range, namely Very High, means that compensation at the Jambi City Transportation Service is in the Very High criteria. Performance with an average score of 265.3 when viewed on the scale range, namely Very High, meaning that the performance at the Jambi City Transportation Service is in the Very High criteria. Increasing compensation through stronger performance, increasing employee compensation will result in higher employee performance. The increase in compensation with the performance of the Jambi City Transportation Service employee has a coefficient of determination known from the value $(R 2)$ of 0.238 so that it can be interpreted that the increase given by the compensation variable on performance is positive. This condition means that this figure states that the compensation variable $(X)$ is able to explain the employee performance variable $(Y)$ at the Jambi City Transportation Service of 23.8\%, whereas $76.2 \%$ is caused by other variables outside the variables studied. Compensation and Performance at the Jambi City Transportation Service is categorized as Very High. Based on the hypothesis test, it is known that there is a significant increase in the Jambi City Transportation Service Office, this is evidenced by the tcount $4.073>$ ttable 1.67412.
\end{abstract}

\section{Keyword: Compensation, Performance and Employes}

\section{Pendahuluan}

Sumber daya manusia merupakan hal terpenting dalam suatu organisasi baik organisasi pemerintah maupun organisasi swasta untuk mencapai tujuan atau target yang ingin dicapai. Sumber daya manusia menjadi penentu dalam tercapainya tujuan dari organisasi atau perusahaan dengan mengoptimalkan kinerja dan kontribusi secara efektif dalam kegiatan di dalam organisasi. Oleh karena itu kemajuan organisasi ditentukan pula oleh kualitas dan kapasitas sumber daya manusia yang ada di dalamnya. Menurut Bangun (2012) salah satu sumber daya organisasi yang memiliki peran penting dalam mencapai tujuannya adalah sumber daya manusia. Oleh karena itu peran manusia sangat penting dalam jangka pendek maupun jangka panjang dalam suatu organisasi pemerintahan. Suatu cara yang berkaitan dengan sumber daya manusia agar dapat menjadi sumber daya keunggulan bersaing adalah melalui peningkatan modal manusia untuk dapat mengenal, beradaptasi, dengan lingkungan yang selalu berubah. Sumber daya manusia merupakan salah satu unsur yang sangat menentukan keberhasilan suatu organisasi mencapai tujuan, orang merupakan suatu unsur yang sangat penting dalam organisasi. Untuk mencapai salah satu tujuan organisasi salah satu hal yang perlu dilakukan pimpinan adalah memberikan daya pendorong yang mengakibatkan, menyalurkan dan memelihara pegawai agar bersedia bekerja sesuai dengan yang diinginkan organisasi.

Tabel 1

Jumlah Pegawai Pada Dinas Perhubungan Kota Jambi Tahun 2016-2020

\begin{tabular}{|c|c|c|}
\hline Tahun & Jumlah Pegawai (orang) & Perkembangan $(\%)$ \\
\hline 2016 & 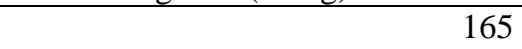 & ( \\
\hline 2017 & 184 & $11.51 \%$ \\
\hline 2018 & 209 & $13.58 \%$ \\
\hline 2019 & 213 & $1.91 \%$ \\
\hline 2020 & 124 & $(41.78) \%$ \\
\hline
\end{tabular}

Sumber : Dinas Perhubungan Kota Jambi Tahun 2020

Tabel 1 diatas terlihat bahwa perkembangan pegawai Dinas Perhubungan Kota Jambi dari tahun 2016 yaitu berjumlah 165 orang pegawai, pada tahun 2017 terjadi peningkatan pegawai menjadi 184 orang atau naik sekitar $11.51 \%$ dan terjadi penurunan jumlah pegawai pada tahun 2020 menjadi 124 orang. Penurunan pegawai pada tahun 2020 tersebut dikarenakan pensiun, meninggal, pindah, oleh karena itu untuk menjamin tersedianya tenaga kerja masa kini ataupun masa depan diberikan kompensasi untuk pegawai yang sebanding pada Dinas Perhubungan Kota Jambi. 
Kompensasi (balas jasa) merupakan suatu hal yang penting dalam instansi, karena hak ini merupakan tujuan utama bagi pegawai untuk bersedia bekerja giat dan bekerja semangat. Bagi pegawai, kompensasi merupakan pendapatan dan sekaligus merupakan jaminan bagi kelangsungan hidup pegawai tersebut beserta keluarganya. Oleh sebab itu, pegawai sangat berkepentingan terhadap besarnya kompensasi yang diterima sebagai kontribusi tenaga dan keahlian yang telah diberikannya kepada instansi.

Tabel 2

Gaji Pegawai Dinas Perhubungan Kota Jambi Tahun 2016- 2020

\begin{tabular}{|c|c|c|c|c|c|c|}
\hline Pangkat/Golongan & Jumlah Pegawai & $\mathbf{2 0 1 6}$ & $\mathbf{2 0 1 7}$ & $\mathbf{2 0 1 8}$ & $\mathbf{2 0 1 9}$ & $\mathbf{2 0 2 0}$ \\
\hline $\mathrm{I} / \mathrm{a}$ & - & - & - & - & - & - \\
\hline $\mathrm{I} / \mathrm{b}$ & 1 & 1.740 .200 & 1.844 .700 & 1.955 .400 & 1.955 .400 & 1.955 .400 \\
\hline $\mathrm{I} / \mathrm{c}$ & 1 & 1.813 .800 & 1.922 .700 & 2.038 .300 & 2.038 .300 & 2.038 .300 \\
\hline $\mathrm{I} / \mathrm{d}$ & - & 1.890 .600 & 2.004 .000 & 2.124 .300 & 2.124 .300 & 2.124 .300 \\
\hline $\mathrm{II} / \mathrm{a}$ & 1 & 2.163 .200 & 2.293 .000 & 2.430 .600 & 2.430 .600 & 2.430 .600 \\
\hline $\mathrm{I} / \mathrm{b}$ & 22 & 2.254 .700 & 2.390 .000 & 2.533 .400 & 2.533 .400 & 2.533 .400 \\
\hline $\mathrm{II} / \mathrm{c}$ & 40 & 2.350 .100 & 2.491 .100 & 2.640 .600 & 2.640 .600 & 2.640 .600 \\
\hline $\mathrm{I} / \mathrm{d}$ & 3 & 2.449 .500 & 2.596 .400 & 2.752 .300 & 2.752 .300 & 2.752 .300 \\
\hline $\mathrm{II} / \mathrm{a}$ & 9 & 2.802 .000 & 2.970 .100 & 3.148 .300 & 3.148 .300 & 3.148 .300 \\
\hline $\mathrm{II} / \mathrm{b}$ & 25 & 2.920 .500 & 3.095 .700 & 3.281 .500 & 3.281 .500 & 3.281 .500 \\
\hline $\mathrm{II} / \mathrm{c}$ & 8 & 3.044 .000 & 3.226 .700 & 3.420 .300 & 3.420 .300 & 3.420 .300 \\
\hline $\mathrm{III} / \mathrm{d}$ & 10 & 3.172 .800 & 3.363 .200 & 3.565 .000 & 3.565 .000 & 3.565 .000 \\
\hline $\mathrm{IV} / \mathrm{a}$ & 2 & 3.307 .000 & 3.505 .400 & 3.715 .800 & 3.715 .800 & 3.715 .800 \\
\hline $\mathrm{IV} / \mathrm{b}$ & 2 & 3.446 .900 & 3.653 .700 & 3.873 .000 & 3.873 .000 & 3.873 .000 \\
\hline
\end{tabular}

Sumber Data : Dinas Perhubungan Kota Jambi

Berdasarkan Tabel 2 diatas jumlah keseluruhan total kompensasi yang diberikan untuk keseluruhan pegawai Dinas Perhubungan Kota Jambi mengalami kenaikan yaitu pada setiap tahun 2016-2020. Dari tabel diatas dapat kita lihat bahwa kompensasi yang diterima cukup stabil dan sesuai dengan setiap golongan pegawai, oleh karena itu pegawai harus memiliki kinerja yang tinggi dalam melakukan suatu pekerjaan. Peningkatan kinerja merupakan hal yang diinginkan baik dari pihak pemberi kerja maupun para pekerja. Pemberi kerja menginginkan kinerja karyawan baik untuk kepentingan peningkatan hasil kerja dan keuntungan perusahaan. Disisi lain, para pekerja berkepentingan untuk pengembangan diri dan promosi pekerjaan. Secara umum, dapat dikatakan bahwa kinerja karyawan yang baik bertujuan untuk meningkatkan produktivitas. (Bangun, 2012). Kinerja menurut Sedarmayanti (2018) adalah hasil kerja seseorang karyawan selama periode tertentu dibandingkan dengan berbagai kemungkinan, missal : standar/sasaran/kriteria yang ditentukan dan disepakati bersama. Kinerja menurut Fahmi (2018) adalah hasil yang diperoleh oleh suatu organisasi baik organisasi tersebut bersifat profit oriented dan non profit oriented yang dihasilkan selama satu periode waktu.

Diberlakukannya UU No. 32/2004 tentang pemerintahan daerah atau otonomi daerah membawa konsekuensi logis bagi pemerintah daerah yaitu adanya tuntutan pemberdayaan aparatur dalam memberikan pelayanan masyarakat yang lebih professional, responsive dan transparan untuk itu setiap instansi dituntut agar mau dan mampu memberikan pelayanan yang baik kepada masyarakat serta memiliki kinerja yang baik. Dalam sebuah organisasi, diperlukan suatu pembinaan bagi pegwai untuk mencegah terjadinya pelanggaran terhadap ketentuan yang telah ditetapkan, Penerapan disiplin bagi pegawai diharapkan dapat meningkatkan kinerja pegawai karena semakin baik disiplin pegawai, seamakin tinggi prestasi kerja atau kinerja yang dapat dicapainya, tanpa disiplin yang baik, sulit bagi organisasi perusahaan mencapai hasil yang optimal. Disiplin yang baik mencerminkan besarnya rasa tanggung jawab seseorang terhadap tugas-tugas yang diberikan kepadanya. Hal ini mendorong gairah kerja, semangat kerja, dan terwujudnya tujuan perusahaan, pegawai dan masyarakat. 
Tabel 3

Realisasi Pelaksanaan Program dan Kegiatan Pada Dinas Perhubungan Kota Jambi Tahun 2016-2020

\begin{tabular}{|c|c|c|c|c|}
\hline Tahum & Program Kerja & Bidang & Target & Realisasi \\
\hline \multirow{3}{*}{2016} & Peningkatan sarana prasarana lalu lintas dan angkutan dalam kota jambi & Operasional & $90 \%$ & $50 \%$ \\
\hline & $\begin{array}{l}\text { Peningkatan pengawasan lalu lintas dalam rangka mengurangi jangka kemacetan lalu } \\
\text { lintas kota jambi }\end{array}$ & Lalu Lintas & $100 \%$ & $100 \%$ \\
\hline & $\begin{array}{l}\text { Peningkatan fungsi dalam rangka meningkatkan pendapatan asli daerah dari sektor } \\
\text { retribusi parkir }\end{array}$ & Parkir & $100 \%$ & $76 \%$ \\
\hline \multirow{3}{*}{2017} & Peningkatan sarana prasarana lalu lintas dan angkutan dalam kota jambi & Operasional & $90 \%$ & $58 \%$ \\
\hline & $\begin{array}{l}\text { Peningkatan pengawasan lalu lintas dalam rangka mengurang jangka kemacetan lalu } \\
\text { lintas kota jambi }\end{array}$ & Lalu Lintas & $100 \%$ & $100 \%$ \\
\hline & $\begin{array}{l}\text { Peningkatan fungsi dalam rangka meningkatkan pendapatan asli daerah dari sektor } \\
\text { retribusi parkir }\end{array}$ & Parkir & $100 \%$ & $76 \%$ \\
\hline \multirow{3}{*}{2018} & Peningkatan sarana prasarana lalu lintas dan angkutan dalam kota jambi & Operasional & $90 \%$ & $65 \%$ \\
\hline & $\begin{array}{l}\text { Peningkatan pengawasan lalu lintas dalam rangka mengurangi jangka kemacetan lalu } \\
\text { lintas kota jambi }\end{array}$ & Lalu Lintas & $100 \%$ & $100 \%$ \\
\hline & $\begin{array}{l}\text { Peningkatan fungsi dalam rangka meningkatkan pendapatan asli daerah dari sektor } \\
\text { retribusi parkir }\end{array}$ & Parkir & $100 \%$ & $80 \%$ \\
\hline \multirow{3}{*}{2019} & Peningkatan sarana prasarana lalu lintas dan angkutan dalam kota jambi & Operasional & $90 \%$ & $73 \%$ \\
\hline & $\begin{array}{l}\text { Peningkatan pengawasan lalu lintas dalam rangka mengurangi jangka kemacetan lalu } \\
\text { lintas kota jambi }\end{array}$ & Lalu Lintas & $100 \%$ & $100 \%$ \\
\hline & $\begin{array}{l}\text { Peningkatan fungsi dalam rangka meningkatkan pendapatan asli daerah dari sektor } \\
\text { retribusi parkir }\end{array}$ & Parkir & $100 \%$ & $85 \%$ \\
\hline \multirow{3}{*}{2020} & Peningkatan sarana prasarana lalu lintas dan angkutan dalam kota jambi & Operasional & $90 \%$ & $90 \%$ \\
\hline & $\begin{array}{l}\text { Peningkatan pengawasan lalu lintas dalam rangka mengurangi jangka kemacetan lalu } \\
\text { lintas kota jambi }\end{array}$ & Lalu Lintas & $100 \%$ & $100 \%$ \\
\hline & $\begin{array}{l}\text { Peningkatan fungsi dalam rangka meningkatkan pendapatan asli daerah dari sektor } \\
\text { retribusi parkir }\end{array}$ & Parkir & $100 \%$ & $100 \%$ \\
\hline
\end{tabular}

Sumber : Dinas Perhubungan Kota Jambi Tahun 2020

Berdasarkan Tabel 3 dijelaskan bahwa program kerja pada Dinas Perhubungan Kota Jambi menunjukan kinerja input dan output yang cukup baik, Dalam tingkat realisasi kegiatan yang berjumlah 3 buah pada tahun 2016, terlihat realisasi tertinggi yang sesuai rencana awal yaitu $100 \%$ dan realisasi terendah yaitu 58\% dan dapat disimpulkan bahwa kinerja para pegawai Dinas Perhubungan Kota Jambi rata-rata belum optimal. Tujuan penelitian ini adalah bagaimana pengauh kompensasi dan kinerja pegawai pada Dinas Perhubungan Kota Jambi.

\section{Landasan Teori}

\section{Kompensasi}

Menurut Fahmi (2018) Kompensasi merupakan salah satu fungsi yang penting dalam manajemen sumber daya manusia (MSDM). Karena kompensasi merupakan salah satu aspek yang paling sensitive di dalam hubungan kerja. Kasus yang terjadi dalam hubungan kerja mengandung masalah kompensasi dan berbagai segi yang terkait, seperti tunjangan, kenaikan kompensasi, struktur kompensasi, dan skala kompensasi. Kompensasi merupakan sesuatu yang diterima karyawan sebagai pengganti kontribusi jasa mereka pada perusahaan. Pemberian kompensasi merupakan salah satu pelaksanaan fungsi MSDM yang berhubungandengan semua jenis pemberian penghargaan individual sebagai pertukaran dalam melakukan tugas keorganisasian. Menurut Hasibuan (2016) Faktor-faktor yang mempengaruhi besarnya kompensasi, antara lain sebagai berikut: Penawaran dan permintaan tenaga kerja; kemampuan dan kesediaan perusahaan; serikat buruh/organisasi karyawan; produktivitas kerja karyawan; pemerintah dengan undang-undang dan keppresnya; biaya hidup/cost of living; posisi jabatan karyawan; pendidikan dan pengalaman karyawan.; kondisi perekonomian nasional; dan jenis dan sifat pekerjaan. Selanjutnya tujuan kompensasi adalah sebagai ikatan kerja sama, kepuasan kerja, pengadaan efektif, motivasi, stabilitas karyawan, disiplin, pengaruh serikat buruh, dan pengaruh pemerintah. Menurut Rivai (2015), Komponen-komponen kompensasi sebagai berikut: gaji, upah, insentif, dan kompensasi tidak langsung

\section{Kinerja}

Menurut Rivai (2015), kinerja adalah suatu tampilan keadaan secara utuh atas perusahaan selama waktu periode tertentu, merupakan hasil atau prestasi yang dipengaruhi oleh kegiatan operasional perusahaan dalam memanfaatkan sumber-sumber daya dimiliki. Mangkunegara (2017), kinerja adalah hasil kerja secara kualitas dan kuantitas yang dicapai oleh seorang pegawai dalam melaksanakan tugasnya sesuai dengan tanggung jawab yang diberikan kepadanya. Sedangkan Sedarmayanti (2018) menyebutkan ada 5 (lima) indikator untuk mengukur kinerja seseorang yaitu: kualitas kerja (quality of work), ketetapan waktu (promptness), inisiatif (initiative), kemampuan (capability), komunikasi (communication)

\section{Hubungan Kompensasi Terhadap Kinerja}

Hubungan antara kompensasi dengan kinerja pegawai sangat erat sekali, yaitu hubungan sebab-akibat (causally related). Oleh karena itu hubungan antara kompensasi pegawai dengan kinerja adalah sangat erat dan penting sekali, relevansinya ada dan kuat, bahkan pegawai apabila ingin meningkatkan kinerja, seharusnya memiliki 
kompentensi yang sesuai dengan tugas pekerjaannya. Oleh karena itu pengelolaan sumber daya manusia memang harus dikelola secara benar dan seksama agar tujuan dan sasaran organisasi dapat dicapai melalui pengelolaan sumber daya manusia yang optimal. Kemudian ada beberapa tindakan manajemen yang harus dilakukan proses mengelola sumber daya manusia yang meliputi beberapa proses, antara lain organisasi harus mengidentifikasi dan mengembangkan kompensasi individu kearah kinerja pegawai. Berdasarkan kegiatan tersebut, maka pengelolaan sumber daya manusia harus mengacu dan mengarah pada visi dan misi, strategi serta sasaran organisasi.

\section{Metode}

Metode penelitian yang digunakan dalam penelitian ini adalah metode deskriptif dan kuantitatif. Metode deskriftif kuantitatif bertujuan untuk menggambarkan sifat sesuatu yang tengah berlangsung pada saat riset dilakukan dan memeriksa sebab-sebab dari suatu gejala tertentu. Data dapat diartikan sebagai keterangan-keterangan tentang suatu hal, dapat berupa sesuai yang diketahui. Menurut Syekh (2011) dalam penggunaannya data dapat diklasifikasikan menjadi data primer dan data sekunder. Populasi adalah wilayah yang terdiri atas: obyek/subyek yang mempunyai kualitas dan karakteristik tertentu yang ditetapkan oleh peneliti untuk dipelajari dan ditarik kesimpulan (Sugiyono, 2017). Populasi dalam penelitian ini terdiri dari seluruh pegawai Dinas Perhubungan Kota Jambi yaitu sebanyak 124 orang yang dijadikan sampel. Ukuran sampel merupakan banyaknya sampel yang akan diambil dari suatu populasi. Rumus yang digunakan dalam pengambilan sampel ini adalah berdasarkan rumus Slovin (Umar, 2003)

$n=\frac{N}{1+N(e)^{2}}$

Dimana $: \mathrm{n}=$ Junlah Sampel; N= Populasi; e = Persentase kelonggaran ketidak telitian $(10 \%)$

Jumlah populasi yang akan diteliti telah ditentukan dengan jumlah sebanyak 124 orang, maka dari data tersebut didapatkan ukuran sampel sebagai berikut :

$n=\frac{124}{1+124(10 \%)^{2}}=\frac{124}{2,24}=55$

Analisis deskriptif digunakan dengan bantuan skala likert dengan menggunakan kuesioner. Pengukuran masingmasing indikator kompensasi dan kinerja pegawai diatas menggunkan pendekatan nilai interval. Skala pengukuran untuk tiap dimensi dapat dicari dengan menghitung interval sebagai berikut :

Skor terendah : bobot terendah x jumlah sampel; Skor terendah : 1 x $55=55$

Skor tertinggi : bobot tertinggi x jumlah sampell Skor tertinggi : 5 x $55=275$

Sedangkan untuk mencari rentang skala menurut umar (2003) digunakan rumus sebagai berikut:

Rentang Skala $=\frac{\mathrm{n}(\mathrm{m}-1)}{\mathrm{m}}$

Dimana : $\mathrm{n}=$ Jumlah Sampel; $\mathrm{m}=$ Jumlah alternative jawaban item

Rentang Skala $=\frac{55(5-1)}{5}=44$

Maka didapat interval frekuensi sebagai berikut :

55 - 98 = Sangat Rendah

$99-142=$ Rendah

$143-186=$ Sedang

$187-230=$ Tinggi

$231-275=$ Sangat Tinggi

Analisis regresi linear digunakan untuk mengetahui jenis hubungan antar variable yang diteliti, persamaan regresi Menurut Supranto (2015) persamaan regresi sederhana X terhadap Y adalah sebagai berikut : $Y=a+b x+e$ Keterangan : $\mathrm{a}=$ Konstanta $\mathrm{X}=$ Disiplin; $\mathrm{b}=$ Koefesiensi Regresi $\mathrm{Y}=$ Kinerja Pegawail $\mathrm{e}=$ error

Uji determinasi $\left(\mathrm{R}^{2}\right)$ merupakan suatu ukuran yang penting dalam regresi, karena dapat mengimpormasikan baik atau tidaknya model regresi yang terestimasi atau dengan kata lain angka tersebut dapat mengukur seberapa dekatkah garis regresi yang terestimasi dengan data yang sesungguhnya. Nilai koefisien determinasi $\left(R^{2}\right)$ ini mencerminkan seberapa besar variasi dan variabel terikat $\mathrm{Y}$ dapat diterangkan oleh variabel bebas $\mathrm{X}$. Bila nilai koefisien determinasi sama dengan $0\left(\mathrm{R}^{2}=0\right)$, artinya variasi $\mathrm{Y}$ tidak dapat diterangkan sama sekali. Sementara bila $\mathrm{R}^{2}=1$, artinya variasi $\mathrm{Y}$ secara keseluruhan dapat diterangkan oleh $\mathrm{X}$, dengan kata lain bila $\mathrm{R}^{2}=1$, maka semua titik pengamatan berada tepat pada garis regresi. Dengan demikian baik atau buruknya suatu persamaan regresi ditentukan oleh $\mathrm{R}^{2}$ nya yang mempunyai nilai 0 dan 1 .

Uji t digunakan untuk menentukan apakah variabel disiplin $(X)$ berpengaruh secara signifikan menggunakan variabel kinerja pegawai $(\mathrm{Y})$ rumus yang digunakan adalah :

1. Rancangan Hipotesis

$\mathrm{H}_{0}$ : Tidak ada pengaruh positif dan sigmifikan, Disiplin Kinerja pegawai. 
$\mathrm{H}_{1}$ : Ada pengaruh positif dan signifikan, disiplin terhadap kinerja pegawai.

2. Menghitung $\mathrm{t}$ tabel menentukan nilai $\mathrm{T}_{\text {tabel }}$ yaitu didapat dari pembaca table distribusi $\mathrm{t}$ untuk taraf signifikan $(\alpha$ tertentu) dan $\mathrm{dk}=\mathrm{n}-\mathrm{k}-1$. Dalam hal ini $\mathrm{n}=$ banyak pasang data (sampel unit analisis) dan $\mathrm{k}$ - banyaknya variabel bebas.

3. Kriteria Keputusan

Jika $t_{\text {hitung }}>t_{\text {tabel }}$ artinya $\mathrm{H}_{0}$ ditolak, dan $\mathrm{H}_{1}$ diterima artinya terdapat pengaruh signifikan antara disiplin kerja terhadap kinerja pegawai.

Jika $t_{\text {hitung }} \leq t_{\text {tabel }}$ artinya $\mathrm{H}_{0}$ diterima dan $\mathrm{H}_{1}$ ditolak artinya tidak terdapat pengaruh signifikan antara disiplin kerja terhadap kinerja pegawai.

\section{Hasil}

Tabel 4

Rekapitulasi Terhadap 13 Pernyataan Kompensasi

\begin{tabular}{|c|c|c|c|c|}
\hline No. & Indikator & Sub Indikator & Skor & Keterangan \\
\hline \multirow{4}{*}{1} & \multirow{4}{*}{ Gaji } & Gaji yang diterima sesuai dengan kinerja & 253 & Sangat Tinggi \\
\hline & & Gaii yang diterima sesuai dengan tingkat pendidikan dan jabatan & 256 & Sangat Tingg \\
\hline & & Gaji yang diterima bisa digunakan untuk memenuhi kebutuhan hidup & 270 & Sangat Tingg \\
\hline & & Gaji yang diberikan selalu tepat waktu & 274 & Sangat Tingg \\
\hline \multirow{3}{*}{2} & \multirow{3}{*}{ Insentif } & Pemberian insentif yang diterima sesuai dengan beban kerja & 273 & Sangat Tinggi \\
\hline & & Pemberian insentif yang diterima sesuai waktu yang diterapkan & 271 & Sangat Tinggi \\
\hline & & Insentif yang diberikan sesuai dengan peranan / posisi instansi & 270 & Sangat Tinggi \\
\hline \multirow{3}{*}{3} & \multirow{3}{*}{ Tunjangan } & Tunjangan hari raya dapat digunakan untuk memenuhi kebutuhan hari rava & 271 & Sangat Tingg \\
\hline & & Tunjangan yang diberikan sesuai dengan jabatan & 273 & Sangat Tinggi \\
\hline & & Tunjangan kesehatan yang diberikan sesuai standar tenaga kerja & 268 & Sangat Tinggi \\
\hline \multirow{2}{*}{4} & \multirow{2}{*}{ Fasilitas } & Instansi memberikan alat dan fasilitas kantor yang sesuai dengan kebutuhan setiap bagian & 269 & Sangat Tinggi \\
\hline & & Pemberian Pakaian Dinas yang layak kepada pegawai & 271 & Sangat Tinggi \\
\hline \multicolumn{3}{|r|}{ Total } & 3,219 & \\
\hline & & Rata-Rata & 268,2 & Sangat Tinggi \\
\hline
\end{tabular}

Sumber : Data diolah

Tabel 4 diketahui bahwa tanggapan responden Sangat Tinggi dengan 12 pernyataan indikator kompensasi yang ditanyakan rata-rata skornya sebesar 268,2 .

Tabel 5

Rekap Jawaban Indikator Kompensasi

\begin{tabular}{clccc}
\hline No. & & Indikator & Skor Rata-rata & Keteranagan \\
\hline 1 & Gaji & & 263,2 & Sangat Tinggi \\
2 & Insentif & & 271,3 & Sangat Tinggi \\
3 & Tunjangan & & 270,6 & Sangat Tinggi \\
4 & Fasilitas & & 270,0 & Sangat Tinggi \\
\hline
\end{tabular}

Sumber : Data diolah

Tabel 5 diketahui bahwa jawaban responden tertinggi berkaitan dengan Insentif total skornya sebesar 271,3, sedangkan jawaban terendah berkaitan dengan Gaji total skornya sebesar 263,2.

Tabel 6

Rekap Variabel Kinerja Terhadap 5 Indikator

\begin{tabular}{|c|c|c|c|c|}
\hline No. & Indikator & Sub indicator & Skor & Keterangan \\
\hline \multirow[t]{2}{*}{1} & \multirow{2}{*}{ Kualitas Kerja } & Memiliki tingkat ketelitian yang baik dalam menyelesaikan pekerjaannya & 254 & Sangat Tinggi \\
\hline & & Memiliki keterampilan yang baik dalam menyelesaikan pekerjaanya & 266 & Sangat Tinggi \\
\hline \multirow[t]{2}{*}{2} & \multirow[t]{2}{*}{ Ketepatan Waktu } & Dapat menyelesaikan pekerjaan sesuai dengan waktu yang ditetapkan & 261 & Sangat Tingg \\
\hline & & Dapat menyesuaikan pekerjaan sesuai dengan berat ringannya pekerjaan yang ditangani & 270 & Sangat Tinggi \\
\hline \multirow[t]{2}{*}{3} & \multirow[t]{2}{*}{ Inisiatif } & Volume kerja yang dihasilkan dalam kondisi yang sesuai dengan batas waktu dan jadwal yang ditentukan & 266 & Sangat Tinggi \\
\hline & & Bersedia melakukan pekerjaan tanpa harus diperintah atau diminta dahulu oleh atasan & 270 & Sangat Tinggi \\
\hline \multirow[t]{2}{*}{4} & \multirow[t]{2}{*}{ Kemampuan } & Pegawai mampu mengikuti aturan yang ditetapkan oleh pemerintah untuk mendapatkan hasil kerja yang baik & 273 & Sangat Tinggi \\
\hline & & Pegawai mampu bekeja sama untuk mencapai tujuan dan target yang telah ditentukan & 268 & Sangat Tinggi \\
\hline \multirow[t]{2}{*}{5} & \multirow[t]{2}{*}{ Komunikasi } & Bahwa informasi dari pimpinan dapat dipahami & 270 & Sangat Tinggi \\
\hline & & Sesama rekan kerja sudah melakukan komunikasi secara baik & 255 & Sangat Tinggi \\
\hline & & Total & 2,653 & \\
\hline & & Rata-rata & 265,3 & Sangat Tinggi \\
\hline
\end{tabular}

Sumber : Data diolah 
Tabel 6 diketahui bahwa tanggapan responden terkait variabel kinerja Sangat Tinggi dengan 5 Indikator yang ditanykan rata-rata skornya sebesar 265,3, jawaban responden tertinggi berkaitan dengan Kemampuan total skornya sebesar 273, sedangkan jawaban terendah berkaitan dengan Kualitas Kerja skornya sebesar 254.

Tabel 7

Rekap Jawaban Indikator Kinerja

\begin{tabular}{clrl}
\hline No. & \multicolumn{1}{c}{ Indikator } & Skor Rata-rata & \multicolumn{2}{c}{ Keterangan } \\
\hline 1 & Kualitas Kerja & 260 & Sangat Tinggi \\
2 & Ketepatan Waktu & 265,5 & Sangat Tinggi \\
3 & Inisiatif & 268 & Sangat Tinggi \\
4 & Kemampuan & 270,5 & Sangat Tinggi \\
5 & Komunikasi & 262,5 & Sangat Tinggi \\
\hline
\end{tabular}

Sumber : Data diolah

Tabel 7 diketahui bahwa jawaban responden tertinggi untuk indikator Kemampuan rata-rata skornya sebesar 270,5. Sedangkan jawaban terendah untuk indikator Kualitas Kerja yaitu rata-rata skornya sebesar 260.

Tabel 8

Persamaan Linear

\begin{tabular}{|l|l|r|r|r|r|r|}
\hline \multirow{2}{*}{ Model } & \multicolumn{2}{|c|}{ Unstandardized Coefficients } & Standardized Coefficients & \multirow{2}{*}{ Sig. } \\
\cline { 2 - 6 } & \multicolumn{2}{|c|}{ B } & Std. Error & Beta & \\
\hline \multirow{2}{*}{1} & (Constant) & 11.983 & 4.432 & & .009 \\
\cline { 2 - 7 } & Kompensasi & .471 & .116 & .488 & 4.073 & .000 \\
\hline
\end{tabular}

Sumber : Data diolah

Berdasarkan keterangan tersebut diketahui persamaan regresinya adalah sebagai berikut :

$\mathrm{Y}=11.983+0,471 \mathrm{X}+\mathrm{e}$

Terdapat hubungan positif antara Kompensasi terhadap kinerja pegawai pada Dinas Perhubungan Kota Jambi:

1. Nilai konstanta sebesar 11.983, artinya jika variabel kompensasi tetap, maka kinerja pegawai pada Dinas Perhubungan Kota Jambi sebesar 11.983.

2. Nilai koefisien variabel Kompensasi sebesar 0,471, artinya jika kompensasi naik $1 \%$ maka kinerja pegawai meningkat sebesar 0,471. Dengan kata lain kompensasi dapat dijadikan sebagai alat untuk memprediksi kinerja pegawai pada Dinas Perhubungan Kota Jambi.

Tabel 9

Koefisien Determinasi

\begin{tabular}{|l|r|r|r|r|r|}
\hline Model & \multicolumn{1}{|c|}{ R } & R Square & Adjusted R Square & Std. Error of the Estimate & Durbin-Watson \\
\hline 1 & $.488^{\mathrm{a}}$ & .238 & .224 & 2.63488 & 1.944 \\
\hline
\end{tabular}

Sumber : Data diolah

Hasil pengujian model summary maka diperoleh nilai determinasi $\left(\mathrm{R}^{2}\right)$ sebesar 0,238 angka ini menyatakan bahwa variabel kompensasi (X) mampu menjelaskan variabel kinerja (Y) pada Dinas Perhubungan Kota Jambi sebesar 0,238 atau $23,8 \%$ sedangkan $76,2 \%$ disebabkan oleh variabel diluar variabel yang diteliti. Dengan demikian ada pengaruh yang signifikan antara variabel kompensasi terhadap kinerja pegawai pada Dinas Perhubungan Kota Jambi.

\section{Analisis Deskriptif Kompensasi dan Kinerja Pada Dinas Perhubungan Kota Jambi}

Kompensasi dengan nilai rata-rata skornya sebesar 268,2 jika dilihat pada rentang skala yaitu Sangat Tinggi artinya kompensasi pada Dinas Perhubungan Kota Jambi berada pada kriteria Sangat Tinggi. Sedangkan Kinerja dengan nilai rata-rata skornya sebesar 265,3 jika dilihat pada rentang skala yaitu Sangat Tinggi artinya kinerja pada Dinas Perhubungan Kota Jambi berada pada kriteria Sangat Tinggi.

\section{Analisis Pengaruh Kompensasi Terhadap Kinerja Dinas Perhubungan Kota Jambi}

Hasil perhitungan persamaan regresi linear sederhana. Analisis regresi menunjukkan bahwa koefisien regresi kompensasi mempunyai arah yang positif terhadap kinerja pegawai pada Dinas Perhubungan Kota Jambi. Koefisien regresi kompensasi (X) sebesar 0,471 artinya jika kompensasi (X) mengalami peningkatan 1\% maka Kinerja Pegawai (Y) pada Dinas Perhubungan Kota Jambi akan mengalami kenaikan sebesar 0,471\%. Dalam penelitian ini telah dibuktikan bahwa kompensasi berpengaruh terhadap kinerja. Semakin kuat kompensasi yang dimiliki pegawai maka mengakibatkan semakin tingginya kinerja pegawai. Pengaruh kompensasi dengan kinerja pegawai Dinas Perhubungan Kota Jambi memiliki koefisien determinasi diketahui dari nilai $\left(R^{2}\right)$ sebesar 0,238 sehingga dapat diartikan bahwa 
pengaruh yang diberikan oleh variabel kompensasi terhadap kinerja adalah positif. Kondisi ini mengandung arti bahwa angka ini menyatakan variabel kompensasi (X) mampu menjelaskan variabel kinerja pegawai (Y) pada Dinas Perhubungan Kota Jambi sebesar 23,8\% sebaliknya 76,2\% disebabkan oleh variabel lain diluar variabel yang diteliti.

\section{Simpulan}

Berdasarkan tujuan penelitian dan hasil pembahasan tentang pengaruh kompensasi terhadap kinerja pegawai yang dilakukan pada Dinas Perhubungan Kota Jambi, maka penulis menarik kesimpulan sebagai berikut:

1. Kompensasi pada Dinas Perhubungan Kota Jambi dikategorikan Sangat Tinggi dengan rata-rata skor responden yaitu 268,2, begitu juga dengan Kinerja pegawai dikategorikan Sangat Tinggi dengan rata-rata skor responden yaitu 265,3 .

2. Kinerja pegawai mempunyai hubungan yang erat, dengan koefisien korelasinya nya adalah 0,488 hal tersebut menunjukkan bahwa kompensasi mampu memberikan hubungan sebesar 48,8\% terhadap kinerja dan memberikan pengaruh dengan koefisien determinasinya sebesar 0,238 hal tersebut menunjukkan bahwa kompensasi mampu memberikan pengaruh sebesar 23,8\% terhadap kinerja pada Dinas Perhubungan Kota Jambi.

\section{Daftar Pustaka}

Bangun, Wilson, 2018, Manajemen Sumber Daya Manusia, Erlangga : Jakarta.

Hasibuan, Malayu S.P. 2016, Manajemen Sumber Daya Manusia, Bumi Aksara. Jakarta.

Irham Fahmi, 2018, Manajemen Sumber Daya Manusia, Teori dan Aplikasi, Alfabeta : Bandung.

Mangkunegara, Anwar P. 2017, Manajemen sumber daya manusia, PT. Remaja Rosda Karya :Bandung.

Sedarmayanti,2018, Manajemen sumber daya manusia, Edisi Revisi , Gramedia Widia sarana Indonesia, Jakarta

Sugiyono, 2017, Statistika Untuk Penelitian, Alfabeta : Bandung.

Supranto, J. 2015, Statistik Teori \& Aplikasi, Erlangga : Jakarta.

Syekh, Sayid. 2011, Pengantar Statistika Ekonomi dan Sosial, Gaung Persada Press Group : Jakarta.

Umar, Husein. 2003, Riset Sumber Daya Manusia Dalam Organisasi, Edisi Revisi, Cetakan Kelima, PT. Gramedia Pustaka Utama : Jakarta.

Veithzal Rivai Zainal, Mansyur Ramly, Thoby Mutis, Willy Arafah. 2015, Manajemen Sumber Daya Manusia Untuk Perusahaan, dari Teori ke Praktik, Edisi Ketiga, Raja Grafindo Persada : Jakarta. 